\title{
Utilization of prune juice or puree as a laxative for constipation pregnant rats induced iron intake during pregnancy and the impact on newborns
}

\author{
El-Dakak Abeer M. N. H., El-Nahal Dalia. M. M., Sayed-Ahmed E. F. \\ Special Food and Nutrition Dept., Food Technology Research Institute, Agric. Res. Center, Giza, Egypt \\ Email address: \\ Abeereldakak@Gmail.com (A. M. N. H. El-Dakak), Elsayed_Frahat2003@yahoo.com (Sayed-Ahmed E. F.), \\ Daliaelnahal@hotmail.com. (D. M. M. El-Nhahal)
}

To cite this article:

El-Dakak Abeer M. N. H., El-Nahal Dalia. M. M., Sayed-Ahmed E. F.. Utilization of Prune Juice or Puree as a Laxative for Constipation Pregnant Rats Induced Iron Intake during Pregnancy and the Impact on Newborns. International Journal of Nutrition and Food Sciences. Vol. 2, No. 6, 2013, pp. 342-351. doi: 10.11648/j.jinfs.20130206.23

\begin{abstract}
Iron supplementation during pregnancy causes constipation in pregnant women and newborn babies; especially on high doses. Prune juice and prune puree were tested to avoid the constipation in pregnant women and newborn babies. Phenolic compounds, vitamin $\mathrm{C}$ and sugar alcohols of prune juice and prune puree were determined. Forty two pregnant female rats fed a basal diet for 6 weeks. At the $10^{\text {th }}$ day of pregnancy they were divided randomly into 7 groups. Group 1, was the negative control (N. control). Rats from group 2 to group 4 fed on basal diet and received $1 \mathrm{mg}$ $\mathrm{Fe}^{2+} / \mathrm{kg}$ b.w. Group 3 and group 4 administered $0.5 \mathrm{ml}$ prune juice and prune puree twice daily, respectively. Moreover, rats from group 5 to group $7 \mathrm{fed}$ on basal diet and received $2.5 \mathrm{mg} \mathrm{Fe}^{2+} / \mathrm{kg}$ b.w. Group 6 and group 7 administered $0.5 \mathrm{ml}$ prune juice and prune puree twice daily, respectively. Group 2 and 5 were considered positive control 1 and 2, respectively. The mothers rats were received $\mathrm{Fe}^{2+}$ (ferrous fumarate dosage form) daily until parturition; however, they were administrated prune juice and prune puree until weaning at the end of experiment ( 42 days). The mothers of rats and puppies were killed at the end of breast feeding. The results of HPLC-UV detector indicated that quantification of phenolic compounds, vitamin $\mathrm{C}$, sorbitol and xylitol in prune puree were higher than prune juice. Concerning the results of biological experiment, it could be noticed that $\mathrm{Fe}^{2+}$ (ferrous fumarate form) significantly decreased the pellet number, weight, and \% moisture of feces in pregnancy, lactating, in male and female infant rats. Moreover, gastrointestinal movements were significantly reduced in rats administrated with 1 or $2.5 \mathrm{mg} \mathrm{Fe} / \mathrm{Kg}$ b.w represented in the G2 and G5 compared to the negative control (G1). Moreover, prune juice and prune puree utilization improved the tested parameters for pregnancy, lactating and infant rats whether they were male or female. The results clearly showed that prune juice or puree can prevent or treat constipation via normalizing the bowel movement resulting from $\mathrm{Fe}^{2+}$ administration in pregnant rats and their puppies (newborn and infant).
\end{abstract}

Keywords: Constipation, Iron Supplementation, Pregnant Rats, Prune Juice, Prune Puree, Newborns

\section{Introduction}

Iron supplementation during pregnancy from the beginning of the fifth month to the end of pregnancy causes constipation in pregnant women and newborn babies; especially on large doses [ 1 \& 2]. Approximately $11-30 \%$ of women suffer from constipation by the third trimester of pregnancy poor fluid intake, iron supplementation, reduced physical activity and hormonal changes all play a part [3].

Constipation is a symptom, not a disease, and it is defined as having a bowel movement fewer than three times per week. It means different things to different people, and it simply means infrequent stools or hard stools, difficulty passing stools (straining) or a sense of incomplete emptying after a bowel movement [4]. The cause of each of these "types" of constipation is probably different.

Almost all people experience constipation at some point in their life, and a poor life style typically is the major cause. However, decreased bowel movements or a delayed transit time in the colon causes constipation.

Iron supplementation during pregnancy, particularly to mothers who are deemed to be iron deficient, has been proven to be of benefit to both mother and child; enhancing the iron stores in the former, to alleviate further iron losses that could occur during delivery or lactation while iron 
deficient anemia is a risk factor for preterm delivery and low birth weight in the latter. However whether iron supplementation is necessary to mothers who are deemed to have normal iron stores, i.e. ferritin $>20 \mu \mathrm{g} / 1$ haemoglobin $>110 \mathrm{~g} / \mathrm{l}$ remains controversial. Since the additional iron requirement for a normal pregnancy is approximately $1 \mathrm{~g}$, it might be presumed that the lack of menstruation during the gestational period, (total iron gain =approximately $200 \mu \mathrm{g}$ ) together with up-regulation of the proteins involved in iron absorption and transfer in the duodenal mucosa, i.e. DcytB, DMT1, Ireg1 and transferrin receptor, would be adequate to provide sufficient iron for the growth of the fetus as well as maintaining the mother's iron stores. The routine use of iron prophylaxis during pregnancy is a subject of considerable debate, some advocating such treatment as routine while others maintain that it should only be used when clinically indicated according to Ward et al. [5]. Iron supplementation of pregnant individuals with adequate iron status may aggravate oxidative stress [6], with the potential for oxidation of lipids and DNA [7], a factor which could contribute to preterm delivery, while the benefits could include the enhancement of the iron stores of the neonates [8], and be beneficial in its mental development [5].

The most common oral iron salts are ferrous sulfate, ferrous fumarate and ferrous gluconate. The standard preparation used in the oral management of iron deficiency anemia is ferrous sulfate. Other salts, such as ferrous gluconate and ferrous fumarate, are as effective as ferrous sulfate when administered in equivalent amounts of elemental iron, but offer no therapeutic advantage and may be more costly. Calculation of dosage for iron preparations should always be based on the amount of elemental iron to be administrated. Ferrous gluconate contains $\square 12 \%$ and ferrous fumarate contains $33 \%$. For iron deficient adults, 50 to $100 \mathrm{mg}$ of elemental iron given orally 3 times daily is usually adequate. Oral iron preparations may cause nausea, vomiting, dyspepsia, constipation, diarrhea or dark stools. These effects are generally dose-related and, with the exception of dark stools, usually subside with continued therapy [9].

Plums (Prunus domestica) and prunes (dried plum) are traditionally thought to relieve constipation and to increase bowel function. The first literature references, according to Ferrer and Boyd [10], date back to 1345, when French observers reported that prunes were a natural intestinal stimulant. Since then, plums and prunes have been recommended for the treatment of constipation, and are even today believed to soften stools and to relieve constipation [11]. Prunes have been shown to increase fecal output in non-constipated men [12].

The laxative action of prunes depends on the prune/plum variety, but could be explained by their relatively high fiber content (17.8 g/100 g) [13], which comprise both soluble and insoluble fiber. Compared to prunes, plums contain only little fiber per $100 \mathrm{~g}$ but still have laxative effect because of other active compounds. Prunes and plums are a source of the sugar alcohols xylitol and sorbitol [13 \& 14]. Xylitol increases gastric emptying and decreases intestinal transit time [15], and transforms the intestinal microbiota into more acid-producing ones [16]. Sorbitol has a laxative effect and brings about changes in intestinal microbiota, too [17]. Prunes and plums also contain phenolic compounds, mainly in the form of neochlorogenic and chlorogenic acids, which may assist in the laxative action [14]. Serious constipation requires medical treatment, that is, laxatives. In mild constipation, nutritional therapy is often preferred. Although prunes and plums are traditionally believed to relieve constipation, in constipation studies they are often combined with other laxative compounds Because prunes and plums would offer a simple solution to relieve constipation, Piirainen et al. [18] examined whether prune juice alone has a laxative effect on the bowel function of those adults who would benefit from nutritional laxatives, that is, adults with certain gastrointestinal symptoms but are otherwise healthy.

The aim of this study was to examine the effects of prune juice or prune puree on the bowel function of pregnant rats, which have iron intake at low or high dosage of $\mathrm{Fe} 2+$ (ferrous fumarate form), which due to constipation in pregnant rats and their impact on newborns. Fecal parameters including number, weight and water content were measured. We found evidence that prune juice or prune puree have anti-constipation effects.

\section{Materials and Methods}

\subsection{Materials}

\subsubsection{Plant Material}

Prunes, dried plum (Prunus domestica L., Family: Rosaceae) California from AlMofk store, Cairo, Egypt.

\subsubsection{Phenolic Standards}

(+)-catechein, pyrogallol, coumaric acid, salicylic acid, cinnamic acid and chrysin were obtained from Aldrich Chemical Co. (Milwaukee. WI). Caffeic acid and caffeine were purchased from Sigma Chemical Co. (St. Louis, MO). Chlorogenic acid (5'-caffeoylquinic acid) was purchased from Fluka Chemical Corp. (Buchs, Switzerland).

\subsubsection{Drug}

Ferrous fumarate was obtained from EVA Pharma for pharmmaceuticals \&Medical Appliances, Egypt.

\subsubsection{Animals}

Forty two pregnant female albino rats on the three day of pregnancy, average weight, of $200 \pm 5 \mathrm{~g}$, were obtained and housed individually in the Ophthalmology Research Institute, Giza, Egypt. The rats were kept under normal health laboratory conditions and fed on basal diet for one week adaptation period). Water and basal diet were provided ad libitum. Basal diet composition prepared according to Reeves et al. [19]. 


\subsection{Methods}

\subsubsection{Preparation of Prune Puree and Juice}

Prunes puree were prepared from prunes processed in boiling water for $25 \mathrm{~min}$, cooled, blended in a commercial blender and sorted at $4{ }^{\circ} \mathrm{C}$ until used [20].

The test prune juice was prepared from prune puree, and water $(1: 1, \mathrm{w} / \mathrm{v})$ and was sweetened with fructose $(7 \%)$. The juice was pasteurized and sorted at $4{ }^{\circ} \mathrm{C}$ until used [18].

\subsubsection{Determination of Main Components by HPLC}

\subsubsection{Determination of Phenolic Components and Vitamin C}

A high performance liquid chromatography system equipped with a variable wave length detector (Agilent 1100 , Germany) was used. The HPLC was equipped with auto sampler, quaternary pump, degasser and the analytical column used was Tracer Spheriosorb ODS2 $\mathrm{C}_{18}(250 \times 4.6$ $\mathrm{mm}$ I.D., $5 \mu \mathrm{m}$ particle size) to identify and determine phenolic compounds and vitamin $\mathrm{C}$ of prune juice and prune puree.

The method described by Danny et al. [21] was used to determine phenolic acids. HPLC method started with linear gradient at a flow rate of $1.0 \mathrm{ml} / \mathrm{min}$ with mobile phase of water / acetic acid (98: $2 \mathrm{v} / \mathrm{v}$, solvent A) and methanol / acetonitrile (50: 50, v/v, solvent B), starting with $5 \% \mathrm{~B}$ and increasing B to levels of $30 \%$ at $25 \mathrm{~min}, 40 \%$ at $35 \mathrm{~min}$, $52 \%$ at $40 \mathrm{~min}, 70 \%$ at $50 \mathrm{~min}, 100 \%$ at $55 \mathrm{~min}$ and monitoring wave length used was $280 \mathrm{~nm}$. Quantification was carried out using external standardization.

Vitamin C (Ascorbic acid) extracted of prune juice and puree by $0.56 \%(\mathrm{w} / \mathrm{v})$ meta-phosphoric acid solution [22] $50 \mu \mathrm{l}$ of the filtrate was directly injected into the HPLC system. Isocratic chromatographic separation was carried out using a mobile phase of deionized water with acetic acid $(0.1 \%, \mathrm{v} / \mathrm{v})$ and methanol in a relative proportion of 95:5 (v/v). The flow-rate was $0.7 \mathrm{ml} / \mathrm{min}$ and the column temperature was $25 \circ \mathrm{C}$. Ascorbic acid was identified by comparing the retention time of the sample peak with that of the ascorbic standard at $254 \mathrm{~nm}$. Quantification was carried out using external standardization.

\subsubsection{Determination of Sugar Alcohols}

Sorbitol and xylitol of prune juice and prune puree were determined by high-performance chromatography coupled to RI detector. A Hewlett Packard 1100 series, with the same chromatograph mentioned before, consisting of a binary pump, a vacuum-degasser, a manual injector (Rheodyne, U.S.A.), a column heater (Jeatstream, Austria), a signal converter and a RI detector was used. Sorbitol and xylitol concentrations were determined at $80{ }^{\circ} \mathrm{C}$. de-ionized water were used as the mobile phase, with an injection volume $20 \mu \mathrm{L}$ and flow rate of $0.6 \mathrm{~mL} / \mathrm{min}$ and wave length was $275 \mathrm{~nm}$ and the analytical column used was HPX-87C $(8.7 \times 300 \mathrm{~mm})$ to identify and determine and the analytical column used was Carbohydrate HPX-87C (8.7 x $300 \mathrm{~mm}$ ) to identify and determine [23]. Standard solutions were prepared in the same way as the sample by the method described by Papea et al. [24].

\subsubsection{Experimental Protocol}

The experimental diets were conformed to American Institute of Nutrition for laboratory animals [19]. The form of iron (ferrous fumarate) was administered to the rats on $10^{\text {th }}$ day of pregnancy by stomach tube in two concentrations $1 \mathrm{mg} \mathrm{Fe} 2+/ \mathrm{kg}$ b.w. [5] and $2.5 \mathrm{mg} \mathrm{Fe} 2+/ \mathrm{Kg}$ b.w [25] daily until parturition (the end of pregnancy; 21 day of pregnancy). Ferrous fumarate dissolved in distilled water and saturated with nitrogen to diminish oxidation, a new solution was made each day [26].

All the pregnant rats $(n=42)$ were fed control diet $(50 \mathrm{mg}$ $\mathrm{Fe} 2+/ \mathrm{kg}$ diet) for one week, before the experiment, after that on $10^{\text {th }}$ day of pregnancy the rats were weighed and randomly divided into 7 groups each of 6 rats and fed on the basal diet in Table (1) as follows:

Table (1). Daily intake for different tested groups

\begin{tabular}{|c|c|c|c|c|c|c|c|}
\hline $\begin{array}{l}\text { Groups of rats } \\
\text { Daily intake } \\
\end{array}$ & $\begin{array}{l}\text { Group } 1 \\
\text { Negative control } \\
\text { (N. control) }\end{array}$ & $\begin{array}{l}\text { Group } 2 \\
\text { Positive control } \\
1 \text { (P. control 1) }\end{array}$ & Group 3 & Group 4 & $\begin{array}{l}\text { Group } 5 \\
\text { Positive control } 2 \\
\text { (P. control 2) }\end{array}$ & Group 6 & Group 7 \\
\hline Control diet & $\sqrt{ }$ & $\sqrt{ }$ & $\sqrt{ }$ & $\sqrt{ }$ & $\sqrt{ }$ & $\sqrt{ }$ & $\sqrt{ }$ \\
\hline $\begin{array}{l}\mathrm{Fe}^{2+}(\text { Ferrous fumarate } \\
\text { form) } 1 \mathrm{mg} \mathrm{Fe}^{2+} / \mathrm{kg} \text { b.w }\end{array}$ & - & $\sqrt{ }$ & $\sqrt{ }$ & $\sqrt{ }$ & - & - & - \\
\hline $\begin{array}{l}\mathrm{Fe}^{2+} \text { (Ferrous fumarate } \\
\text { form) } 2.5 \mathrm{mg} \mathrm{Fe}^{2+} / \mathrm{kg} \mathrm{b.w}\end{array}$ & - & - & - & - & $\sqrt{ }$ & $\sqrt{ }$ & $\sqrt{ }$ \\
\hline prune juice $0.5 \mathrm{ml}$ & - & - & $\sqrt{ }$ & - & - & $\sqrt{ }$ & \\
\hline prune puree $0.5 \mathrm{ml}$ & - & - & - & - & - & - & $\sqrt{ }$ \\
\hline
\end{tabular}

The rats received $\mathrm{Fe}^{2+}$ (ferrous fumarate form) daily until parturition. Prune juice and prune puree administered twice daily: the first dose at the morning and the other one in the evening until the end of the experiment by stomach tube.

The mothers of rats were killed by diethyl ether at the end of the breast feeding (21:25 days); also the infant rats (male and female) were killed at the same time. The carcasses were dissected.

\subsubsection{Sample Collection}

The number of neonates (male and female) was counted, 
taken six neonates ( 3 male and 3 female), chosen from each mother at random. Maternal and neonates feces samples were collected daily until the end of experiment to determined feces moisture (water content of the feces) according to A.O.A.C. [27], feces weight, pellet number, and examine the form of feces .

\subsubsection{Examination of Intestinal Movement}

To test the effect of prunes juice and puree on gastrointestinal function of pregnant rats and newborns (male and female), the animals were starved for one day and then directly administered $10 \%$ barium sulfate solution into the stomach as much as $1 \mathrm{~mL} / 100 \mathrm{~g}$ of body weight. After $30 \mathrm{~min}$, rats were anesthetized with urethane and sacrificed and then the intestine was separately dissected. The distance the barium sulfate moved in the intestinal tract was measured [28].

\subsubsection{Statistical Analysis}

Values are expressed as means \pm SEs. One-way analysis of variance (ANOVA) was used for multiple comparisons. When ANOVA showed significant differences, post-hoc analysis was performed with the Newman-Keuls multiple range test. SPSS for windows was used for all the analysis, [29].

\section{Results}

\subsection{The Main Component Identification}

Phenolic, flavonoid compounds, vitamin $\mathrm{C}$ and alcoholic sugars (xylitol \& sorbitol) in prune juice and prune puree by HPLC are presented in Table ( $2 \& 3)$.

The qualitative and quantitative of phenolic compounds are presented in Table (2). The data showed that the phenolic compounds of prune juice and prune puree contained catechein, pyrogallol, chlorogenic acid, caffeic acid, caffeine, coumaric acid, salicylic acid, cinnamic acid and chrysin. It could be noticed that phenolic compounds of prune juice were less than of prune puree.

Table (2). Phenolic compounds of prune juice and prune puree

\begin{tabular}{llll}
\hline Compounds & $\begin{array}{l}\text { Prune juice } \\
\mathbf{m l})\end{array}$ & $\begin{array}{l}(\mathbf{m g} / \mathbf{1 0 0} \\
\text { Prune } \\
\mathbf{m l})\end{array}$ & $\begin{array}{l}\text { puree } \\
(\mathbf{m g} / \mathbf{1 0 0}\end{array}$ \\
\hline Catechin & 39.69 & 48.91 \\
Pyrogallol & 78.63 & 87.05 \\
Chlorogenic acid & 32.84 & 38.01 \\
Caffeic acid & 1.97 & 2.89 \\
Caffeine & 1.02 & 1.25 \\
Coumaric acid & 0.39 & 0.48 \\
Salicylic acid & 3.10 & 3.61 \\
Cinnamic & 0.35 & 0.44 \\
Chrysin & 0.15 & 0.19 \\
\hline
\end{tabular}

Data in Table (3) illustrate the content of vitamin $\mathrm{C}$ in prune juice and prune puree. The results clear that the vitamin C was 4.51 and $7.53(\mathrm{mg} / 100 \mathrm{ml})$ in prune juice and prune puree, respectively. Meanwhile, the content of sorbitol in prune juice and prune puree was 51.23 and 78.16 $(\mathrm{mg} / 100 \mathrm{ml})$, respectively. Moreover, the content of Xylitol in prune juice and prune puree was $29.22 \mathrm{mg} / 100 \mathrm{ml}$ and $47.25 \mathrm{mg} / 100 \mathrm{mg}$, respectively.

Table (3). Content of vitamin C, sorbitol and xylitol of prune juice and prune puree $(\mathrm{mg} / 100 \mathrm{ml})$

\begin{tabular}{lll}
\hline Compounds & Prune juice & Prune puree \\
\hline Vitamin C & 4.51 & 7.53 \\
Sorbitol & 51.23 & 78.16 \\
Xylitol & 29.22 & 47.25 \\
\hline
\end{tabular}

\subsection{Physical Examination of Rat Mother's Feces and their Puppies}

The examination of rat mother's feces clear that rats of group (4) and (7) was green, soft blobs with clear cut edges (passed easily). It looks like sausage shape. Feces of rats in group (4) were softer than feces of rats in group (7). In contrast, feces of rats in group (2) and (5) were yellow, separate hard lumps, like nuts (hard to pass). It looks like droppings. Feces of rats in group (5) were harder than feces of rats in group (2). Moreover, feces of rats in groups (3) and (6) lumpy with cracks on its surface, feces of rats in group (1) were normal.

\subsection{Fecal Pellet Parameters}

The fecal pellets number per day for mother, infant (males $\&$ females) rats show in Fig (1, 2 and 3). It could be noticed that $\mathrm{Fe}^{2+}$ (ferrous fumarate form) decreased the pellet number of P. Control 1 (group 2) and P. Control 2 (group 5) compared to normal control rats (group 1). Prune juice and prune puree recovered the pellet number feces.

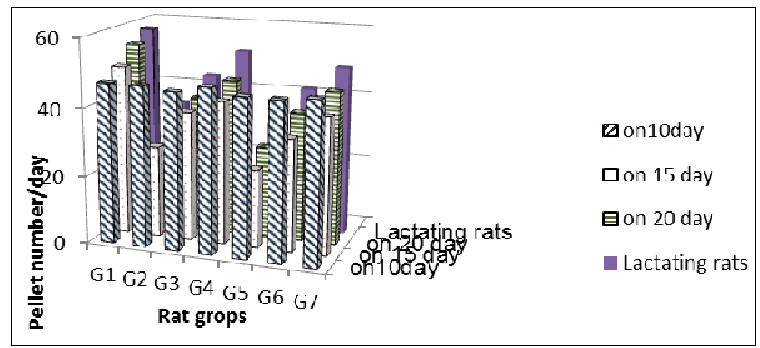

Fig(1): Effect of prune juice and puree on the pellet number feces/day in ferrous fumarate included constipated mother rats

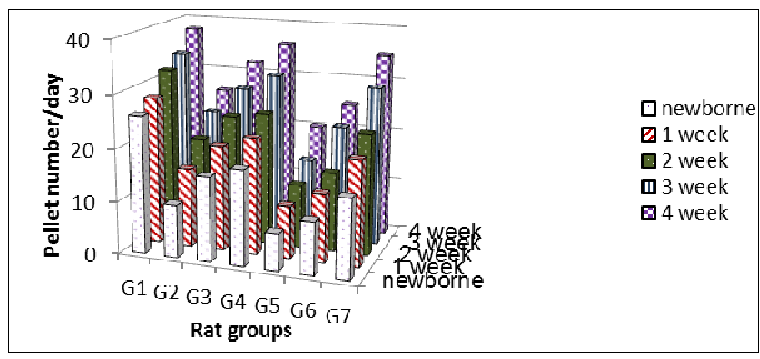

Fig(2): Effect of prune juice and puree on the pellet number feces/day in ferrous fumarate included constipated infant rats 


\subsection{Feces Weight Parameters}

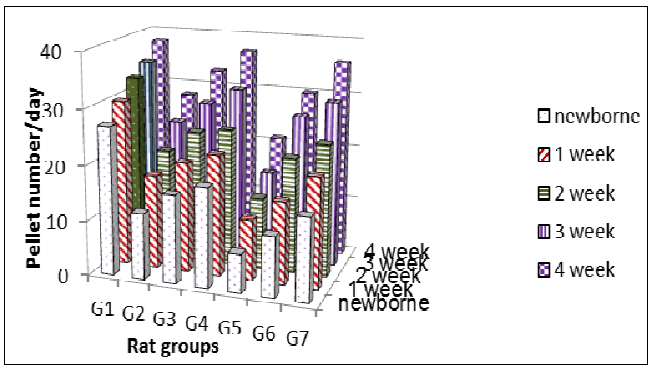

Fig(3): Effect of prune juice and puree on the pellet number feces/day in ferrous fumarate induced constipated in infant femals rats

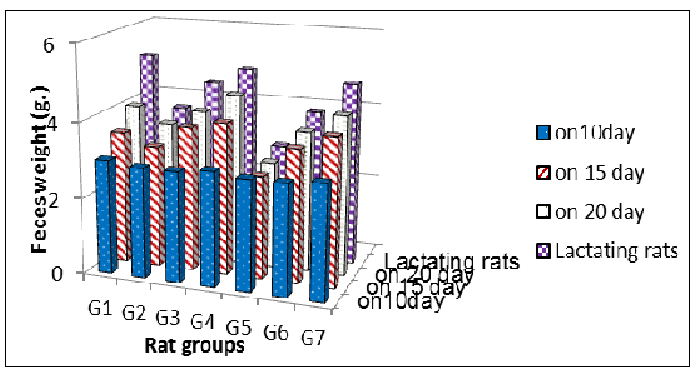

Fig(4): Effect of prune juice and puree on feces weight in ferrous fumarate induced constipated infant mother rats

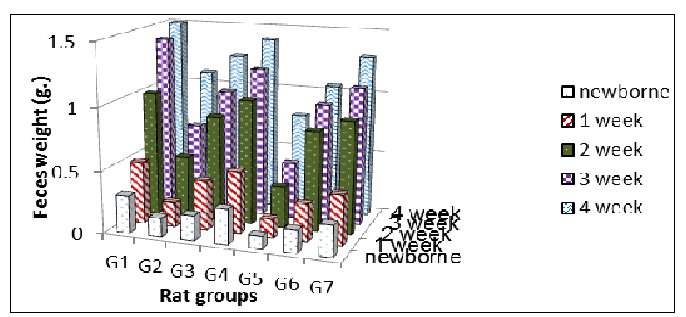

Fig(5): Effect of prune juice and puree on the feces weight in ferrous fumarate induced constipated infant male rats

The feces weight of mother's rats, newborn and infant (males \& female) rats show in Fig (4, 5 and 6). It could be noticed that $\mathrm{Fe}^{2+}$ (ferrous fumarate form) decreased the feces weight of P. Control 1 (group 2) and P. Control 2 (group 5) compared to normal control rats (group 1). Prune juice and prune puree increased the feces weight.
Additionally, high dose of ferrous fumarate was more effect than low dose to less the feces weight.

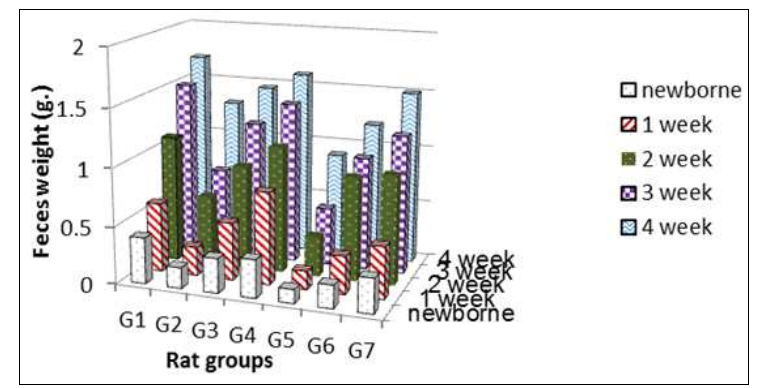

Fig(6): Effect of prune juice and puree on the feces weight in ferrous fumarate induced constipated infant female rats

\subsection{Fecal Moisture (\%) Parameters}

Constipation was assessed principally by fecal moisture to determine the effect of prune juice and prune puree on constipation due to $\mathrm{Fe}^{2+}$ dosage which was utilized in pregnant and as well as its impact on newborn (male \& female) rats.

Data in Table (4) illustrate the effect of prune juice and prune puree on the fecal moisture in pregnant before $\mathrm{Fe}^{2+}$ dosage (on $10^{\text {th }}$ day of pregnancy), after $\mathrm{Fe}^{2+}$ dosage intake (on $15^{\text {th }} \& 20^{\text {th }}$ day of pregnancy) and lactating rats. Fecal moisture was significantly decreased in groups (G2 \& G5) administrated with 1 and $2.5 \mathrm{mg} \mathrm{Fe}{ }^{2+} / \mathrm{kg}$ b.w, respectively compared to the $\mathrm{N}$. control group (G1). After dosage prune juice and prune puree administration recovered the moisture content. However, no difference was found between all experimental groups before dosage. In the general, there are significantly decreased in fecal moisture during pregnancy and during lactating in group 1(n. control). From Table (4) it is clear that prune puree better than prune juice to improve the fecal moisture in all groups which fed both 1 and $2.5 \mathrm{mg} \mathrm{Fe} \mathrm{F}^{2+} / \mathrm{kg}$ b.w. Moreover, the effect of constipation due to $\mathrm{Fe}^{2+}$ gradually disappeared during lactation period.

Table (4). Effect of prune juice and prune puree on the \%moisture of feces in pregnant before $\mathrm{Fe}^{2+}$ dosage (on 10 day of pregnancy), after $\mathrm{Fe}^{2+}$ dosage (on 15 day of pregnancy \& on 20 day of pregnancy) and lactating rats

\begin{tabular}{|c|c|c|c|c|c|}
\hline \multirow[b]{2}{*}{ Rat group } & \multirow[b]{2}{*}{ Daily intake } & \multicolumn{3}{|c|}{$\%$ moisture of feces Pregnant rats } & \multirow[b]{2}{*}{$\begin{array}{l}\text { \%moisture of feces } \\
\text { Lactating rats }\end{array}$} \\
\hline & & $\begin{array}{l}\text { Before dosage }\left(\mathrm{Fe}^{2+}\right) \\
\text { on } 10^{\text {th }} \text { day of } \\
\text { pregnancy }\end{array}$ & $\begin{array}{l}\text { After dosage }\left(\mathrm{Fe}^{2+}\right) \\
\text { on } 15^{\text {th }} \text { day of } \\
\text { pregnancy }\end{array}$ & $\begin{array}{l}\text { on } 20^{\text {th }} \text { day of } \\
\text { pregnancy }\end{array}$ & \\
\hline G1 & N. Control & $44.90 \pm 0.48^{\mathrm{Aa}}$ & $35.92 \pm 1.81^{\mathrm{Ab}}$ & $35.19 \pm 1.14^{\mathrm{Ab}}$ & $26.73 \pm 0.14^{\mathrm{Dc}}$ \\
\hline G2 & $\begin{array}{l}\text { P. Control } 1 \\
\left(1 \mathrm{mg} \mathrm{Fe} e^{2+} / \mathrm{Kg} \mathrm{bw}\right)\end{array}$ & $47.36 \pm 1.64^{\mathrm{Aa}}$ & $22.28 \pm 0.23^{\mathrm{Eb}}$ & $22.11 \pm 0.23^{\mathrm{Eb}}$ & $20.06 \pm 0.47^{\mathrm{Eb}}$ \\
\hline G3 & $\begin{array}{l}1 \mathrm{mg} \mathrm{Fe}^{2+} / \mathrm{Kg} \text { bw } \\
+0.5 \mathrm{ml} \text { prune juice (twice) }\end{array}$ & $42.16 \pm 1.92^{\mathrm{Aa}}$ & $29.95 \pm 0.85^{\mathrm{Cb}}$ & $31.12 \pm 0.03^{\mathrm{Cb}}$ & $33.16 \pm 0.29^{\mathrm{Cb}}$ \\
\hline G4 & $\begin{array}{l}1 \mathrm{mg} \mathrm{Fe}^{2+} / \mathrm{Kg} \text { bw } \\
+0.5 \mathrm{ml} \text { prune puree (twice) }\end{array}$ & $47.77 \pm 2.62^{\mathrm{Aa}}$ & $30.59 \pm 0.19^{\mathrm{BCb}}$ & $33.61 \pm 0.20^{\mathrm{ABb}}$ & $47.31 \pm 1.85^{\mathrm{Aa}}$ \\
\hline G5 & $\begin{array}{l}\text { P. Control } 2 \\
\left(2.5 \mathrm{mg} \mathrm{Fe}^{2+} / \mathrm{Kg} \mathrm{bw}\right)\end{array}$ & $44.95 \pm 2.52^{\mathrm{Aa}}$ & $18.70 \pm 0.48^{\mathrm{Fb}}$ & $19.72 \pm 0.28^{\mathrm{Fb}}$ & $17.95 \pm 0.46^{\mathrm{Eb}}$ \\
\hline G6 & $2.5 \mathrm{mg} \mathrm{Fe}^{2+} / \mathrm{Kg} \mathrm{bw}$ & $43.83 \pm 2.58^{\mathrm{Aa}}$ & $26.02 \pm 0.22^{\mathrm{Dc}}$ & $26.99 \pm 1.28^{\mathrm{Dc}}$ & $31.98 \pm 0.33^{\mathrm{Cb}}$ \\
\hline
\end{tabular}




\begin{tabular}{|c|c|c|c|c|c|}
\hline \multirow[b]{2}{*}{ Rat group } & \multirow[b]{2}{*}{ Daily intake } & \multicolumn{3}{|c|}{ \%moisture of feces Pregnant rats } & \multirow[b]{2}{*}{$\begin{array}{l}\text { \%moisture of feces } \\
\text { Lactating rats }\end{array}$} \\
\hline & & $\begin{array}{l}\text { Before dosage }\left(\mathrm{Fe}^{2+}\right) \\
\text { on } 10^{\text {th }} \text { day of } \\
\text { pregnancy }\end{array}$ & $\begin{array}{l}\text { After dosage }\left(\mathrm{Fe}^{2+}\right) \\
\text { on } 15^{\text {th }} \text { day of } \\
\text { pregnancy }\end{array}$ & $\begin{array}{l}\text { on } 20^{\text {th }} \text { day of } \\
\text { pregnancy }\end{array}$ & \\
\hline & $+0.5 \mathrm{ml}$ prune juice (twice) & & & & \\
\hline G7 & $\begin{array}{l}2.5 \mathrm{mg} \mathrm{Fe}^{2+} / \mathrm{Kg} \mathrm{bw} \\
+0.5 \mathrm{ml} \text { prune puree (twice) }\end{array}$ & $43.53 \pm 0.85^{\mathrm{Aa}}$ & $32.59 \pm 0.17^{\mathrm{Bc}}$ & $31.90 \pm 0.59^{\mathrm{BCc}}$ & $36.58 \pm 1.42^{\mathrm{Bb}}$ \\
\hline
\end{tabular}

Each value represents the mean \pm SE.

The mean values with different superscript alphabets indicate significant differences $(\mathrm{P} \leq 0.05)$ using LSD test

LSD: Row (small letter) \& LSD: Column (capital letter)

Data presented in Table ( $5 \& 6$ ) showed that the effect of prune juice and prune puree on the fecal moisture in newborn and infant (male \& female) rats during experiment. Less valuable fecal moisture was recorded to $8.97 \%$ in newborn males (group 5: rats administrated with $2.5 \mathrm{mg}$ $\mathrm{Fe}^{2+} / \mathrm{Kg}$ b.w), however fecal moisture was $14.15 \%$ in newborn females at the same group. Additionally, the highest value of fecal moisture was $56.14 \%$ in female rats administrated with $2.5 \mathrm{mg} \mathrm{Fe}^{2+} / \mathrm{Kg} \mathrm{b.w} \mathrm{(group} \mathrm{7)} \mathrm{at} \mathrm{the} \mathrm{end}$ of experiment (fourth week), followed by 44.19 in female rats administrated with $1 \mathrm{mg} \mathrm{Fe} e^{2+} / \mathrm{Kg}$ b.w (group 2), this indicated that the effect of iron intake which cause constipation in females lower than in males. Moreover, from presented data in Table $(5 \& 6)$ it could be noticed that at the end of experiment (fourth week) prune juice and prune puree administration improved the fecal moisture for infant rats whether males or females compared to newborns.

Table (5) Effect of prune juice and prune puree on the \%moisture of feces in newborn and infant male rats during experiment

\begin{tabular}{|c|c|c|c|c|c|c|}
\hline \multirow{2}{*}{ Rat group } & \multirow{2}{*}{ Daily intake of mothers group } & \multicolumn{5}{|c|}{$\%$ moisture of feces infant male } \\
\hline & & Newborn & 1 week & 2 week & 3 week & 4 week \\
\hline G1 & N. Control & $21.42 \pm 0.20^{\mathrm{Cc}}$ & $21.82 \pm 0.30^{\mathrm{BCc}}$ & $24.13 \pm 0.99^{\mathrm{Db}}$ & $23.41 \pm 0.36^{\mathrm{Cb}}$ & $30.07 \pm 0.96^{\mathrm{CDa}}$ \\
\hline G2 & $\begin{array}{l}\text { P. Control } 1 \\
\left(1 \mathrm{mg} \mathrm{Fe}^{2+} / \mathrm{Kg} \text { b.w }\right)\end{array}$ & $14.45 \pm 0.32^{\mathrm{Fc}}$ & $15.05 \pm 0.33^{\mathrm{Dc}}$ & $18.02 \pm 0.11^{\mathrm{Eb}}$ & $19.06 \pm 0.44^{\mathrm{Db}}$ & $25.03 \pm 1.20^{\mathrm{Ea}}$ \\
\hline G3 & $\begin{array}{l}1 \mathrm{mg} \mathrm{Fe}^{2+} / \mathrm{Kg} \text { b.w } \\
+0.5 \mathrm{ml} \text { prune juice (twice) }\end{array}$ & $19.02 \pm 0.45^{\mathrm{Eb}}$ & $21.05 \pm 0.73^{\mathrm{Cb}}$ & $26.65 \pm 0.16^{\mathrm{Ca}}$ & $28.53 \pm 0.28^{\mathrm{Ba}}$ & $27.84 \pm 0.35^{\text {Da }}$ \\
\hline G4 & $\begin{array}{l}1 \mathrm{mg} \mathrm{Fe} e^{2+} / \mathrm{Kg} \mathrm{b.w} \\
+0.5 \mathrm{ml} \text { prune puree (twice) }\end{array}$ & $25.03 \pm 0.49^{\mathrm{Ad}}$ & $26.14 \pm 0.33^{\mathrm{Ad}}$ & $33.82 \pm 0.42^{\mathrm{Ac}}$ & $35.67 \pm 0.33^{\mathrm{Ab}}$ & $37.26 \pm 0.87^{\text {Aa }}$ \\
\hline G5 & $\begin{array}{l}\text { P. Control } 2 \\
\left(2.5 \mathrm{mg} \mathrm{Fe}^{2+} / \mathrm{Kg} \text { b.w }\right)\end{array}$ & $8.97 \pm 0.19^{\mathrm{Ge}}$ & $13.99 \pm 0.25^{\mathrm{Dd}}$ & $16.74 \pm 0.82^{\mathrm{Ec}}$ & $19.03 \pm 0.12^{\mathrm{Db}}$ & $24.20 \pm 0.76^{\text {Еа }}$ \\
\hline G6 & $\begin{array}{l}2.5 \mathrm{mg} \mathrm{Fe}^{2+} / \mathrm{Kg} \text { b.w } \\
+0.5 \mathrm{ml} \text { prune juice (twice) }\end{array}$ & $20.30 \pm 0.25^{\mathrm{Dd}}$ & $24.48 \pm 0.25^{\mathrm{ABc}}$ & $24.70 \pm 0.31^{\mathrm{Dc}}$ & $28.51 \pm 0.29^{\mathrm{Bb}}$ & $30.94 \pm 0.60^{\mathrm{Ca}}$ \\
\hline G7 & $\begin{array}{l}2.5 \mathrm{mg} \mathrm{Fe}{ }^{2+} / \mathrm{Kg} \mathrm{b} . \mathrm{w} \\
+0.5 \mathrm{ml} \text { prune puree (twice) }\end{array}$ & $22.74 \pm 0.34^{\mathrm{Bd}}$ & $26.65 \pm 0.11^{\mathrm{Ac}}$ & $30.94 \pm 0.77^{\mathrm{Bb}}$ & $35.76 \pm 0.37^{\mathrm{Aa}}$ & $34.93 \pm 0.65^{\mathrm{Ba}}$ \\
\hline
\end{tabular}

Each value represents the mean $\pm \mathrm{SE}$.

The mean values with different superscript alphabets indicate significant differences $(\mathrm{P} \leq 0.05)$ using LSD test

LSD: Row (small letter) \& LSD: Column (capital letter)

Table (6) Effect of prune juice and prune puree on the \%moisture of feces in newborn and infant female rats during experiment

\begin{tabular}{|c|c|c|c|c|c|c|}
\hline \multirow{2}{*}{ Rat group } & \multirow{2}{*}{ Daily intake of mothers group } & \multicolumn{5}{|c|}{$\%$ moisture of feces infant female } \\
\hline & & Newborn & 1 week & 2 week & 3 week & 4 week \\
\hline G1 & N. Control & $22.14 \pm 0.79^{\mathrm{Db}}$ & $20.96 \pm 0 . .86^{\mathrm{Db}}$ & $22.27 \pm 0.19^{\mathrm{Eb}}$ & $21.91 \pm 0.45^{\mathrm{Cb}}$ & $29.31 \pm 1.86^{\mathrm{Ea}}$ \\
\hline $\mathrm{G} 2$ & $\begin{array}{l}\text { P. Control } 1 \\
\left(1 \mathrm{mg} \mathrm{Fe}{ }^{2+} / \mathrm{Kg} \text { b.w }\right)\end{array}$ & $14.55 \pm 0.03^{\mathrm{Fd}}$ & $17.54 \pm 0.93^{\mathrm{Ec}}$ & $19.11 \pm 0.10^{\mathrm{Fc}}$ & $20.93 \pm 0.54^{\mathrm{CDb}}$ & $25.53 \pm 0.41^{\mathrm{Ea}}$ \\
\hline G3 & $\begin{array}{l}1 \mathrm{mg} \mathrm{Fe}^{2+} / \mathrm{Kg} \text { b.w } \\
+0.5 \mathrm{ml} \text { prune juice (twice) }\end{array}$ & $18.87 \pm 0.31^{\mathrm{Ee}}$ & $23.24 \pm 0.60^{\mathrm{Cd}}$ & $27.92 \pm 0.37^{\mathrm{Cc}}$ & $30.36 \pm 0.83^{\mathrm{Bb}}$ & $34.89 \pm 0.13^{\mathrm{Da}}$ \\
\hline G4 & $\begin{array}{l}1 \mathrm{mg} \mathrm{Fe} e^{2+} / \mathrm{Kg} \mathrm{b} . \mathrm{w} \\
+0.5 \mathrm{ml} \text { prune puree (twice) }\end{array}$ & $38.44 \pm 0.84^{\mathrm{Ab}}$ & $35.59 \pm 0.79^{\mathrm{Ac}}$ & $33.32 \pm 0.51^{\mathrm{Ad}}$ & $37.04 \pm 0.58^{\mathrm{Ab}}$ & $44.19 \pm 0.63^{\mathrm{Ba}}$ \\
\hline G5 & $\begin{array}{l}\text { P. Control } 2 \\
\left(2.5 \mathrm{mg} \mathrm{Fe}^{2+} / \mathrm{Kg} \mathrm{b.w}\right)\end{array}$ & $14.15 \pm 0.20^{\mathrm{Fc}}$ & $13.12 \pm 0.85^{\mathrm{Fc}}$ & $17.76 \pm 0.38^{\mathrm{Gb}}$ & $19.25 \pm 1.02^{\mathrm{Db}}$ & $25.03 \pm 0.50^{\mathrm{Ea}}$ \\
\hline G6 & $\begin{array}{l}2.5 \mathrm{mg} \mathrm{Fe}^{2+} / \mathrm{Kg} \mathrm{b} . \mathrm{w} \\
+0.5 \mathrm{ml} \text { prune juice (twice) }\end{array}$ & $25.56 \pm 0.45^{\mathrm{Cc}}$ & $24.85 \pm 0.09^{\mathrm{Cc}}$ & $25.75 \pm 0.22^{\mathrm{Dc}}$ & $31.00 \pm 0.58^{\mathrm{Bb}}$ & $39.65 \pm 1.26^{\mathrm{Ca}}$ \\
\hline G7 & $\begin{array}{l}2.5 \mathrm{mg} \mathrm{Fe}^{2+} / \mathrm{Kg} \mathrm{b} . \mathrm{w} \\
+0.5 \mathrm{ml} \text { prune puree (twice) }\end{array}$ & $29.68 \pm 1.16^{\mathrm{Bc}}$ & $31.96 \pm 0.75^{\mathrm{Bc}}$ & $32.21 \pm 0.16^{\mathrm{Bc}}$ & $38.95 \pm 0.53^{\mathrm{Ab}}$ & $56.14 \pm 2.85^{\mathrm{Aa}}$ \\
\hline
\end{tabular}

Each value represents the mean $\pm \mathrm{SE}$.

The mean values with different superscript alphabets indicate significant differences $(\mathrm{P}<0.05)$ using LSD test

LSD: Row (small letter) \& LSD: Column (capital letter) 


\subsection{Gastrointestinal and Colon Movement Parameters}

The length $(\mathrm{cm})$ of barium transfer (in gastrointestinal or colon) was significantly reduced in rats administrated with 1 or $2.5 \mathrm{mg} \mathrm{Fe} e^{2+} / \mathrm{Kg}$ b.w represented in the (G2) and (G5) compared to the negative control (G1), event acute shortage in rats administrated with $2.5 \mathrm{mg} \mathrm{Fe}^{2+} / \mathrm{Kg}$ b.w (G5) and greatly enhanced in all prune-treated groups compared to the $\mathrm{Fe}^{2+}$-only groups (G2 \& G5). Importantly, movement of gastrointestinal lengths in the prune juice administrated groups of mothers' rat was similar to the N.control group. Although, there was enhancement in gastrointestinal movement by the prune puree administration in male and female rats groups (G4\&G7), however there are significant difference between them and N. control (Table 7). Additionally, movement of colon lengths in the prune puree administrated groups of male and female rats were similar to the N. control group (Table 8).

Table (7) Effect of prune juice and prune puree on the gastrointestinal movement in rats (mothers, infant males and infant females)

\begin{tabular}{|c|c|c|c|c|}
\hline \multirow{2}{*}{ Rat group } & \multirow{2}{*}{ Daily intake of mothers group } & \multicolumn{3}{|c|}{ gastrointestinal movement [The length $(\mathrm{cm})$ of barium transfer] } \\
\hline & & Mother's rat & Males & Females \\
\hline G1 & N. Control & $90.33 \pm 0.88^{c}$ & $123.00 \pm 3.21^{\mathrm{a}}$ & $175.00 \pm 9.29^{\mathrm{a}}$ \\
\hline G2 & $\begin{array}{l}\text { P. Control } 1 \\
\left(1 \mathrm{mg} \mathrm{Fe}{ }^{2+} / \mathrm{Kg} \text { b.w }\right)\end{array}$ & $68.33 \pm 2.03^{\mathrm{d}}$ & $62.67 \pm 1.45^{\mathrm{d}}$ & $80.33 \pm 0.88^{\mathrm{c}}$ \\
\hline G3 & $\begin{array}{l}1 \mathrm{mg} \mathrm{Fe}^{2+} / \mathrm{Kg} \mathrm{b.w} \\
+0.5 \mathrm{ml} \text { prune juice (twice) }\end{array}$ & $92.33 \pm 1.45^{\mathrm{c}}$ & $90.00 \pm 1.53^{\mathrm{c}}$ & $102.00 \pm 0.33^{\mathrm{b}}$ \\
\hline G4 & $\begin{array}{l}1 \mathrm{mg} \mathrm{Fe}^{2+} / \mathrm{Kg} \mathrm{b} . \mathrm{w} \\
+0.5 \mathrm{ml} \text { prune puree (twice) }\end{array}$ & $159.33 \pm 1.76^{\mathrm{a}}$ & $101.67 \pm 4.17^{\mathrm{b}}$ & $112.83 \pm 0.60^{\mathrm{b}}$ \\
\hline G5 & $\begin{array}{l}\text { P. Control } 2 \\
\left(2.5 \mathrm{mg} \mathrm{Fe}^{2+} / \mathrm{Kg} \mathrm{b.w}\right)\end{array}$ & $44.00 \pm 0.57^{\mathrm{e}}$ & $49.33 \pm 2.33^{\mathrm{e}}$ & $69.16 \pm 0.16^{\mathrm{c}}$ \\
\hline G6 & $\begin{array}{l}2.5 \mathrm{mg} \mathrm{Fe}^{2+} / \mathrm{Kg} \mathrm{bw} \\
+0.5 \mathrm{ml} \text { prune juice (twice) }\end{array}$ & $89.66 \pm 0.88^{\mathrm{c}}$ & $87.5 \pm 0.29^{c}$ & $101.00 \pm 3.21^{\mathrm{b}}$ \\
\hline G7 & $\begin{array}{l}2.5 \mathrm{mg} \mathrm{Fe}^{2+} / \mathrm{Kg} \mathrm{b} . \mathrm{w} \\
+0.5 \mathrm{ml} \text { prune puree (twice) }\end{array}$ & $124.00 \pm 2.08^{\mathrm{b}}$ & $91.17 \pm 0.16^{\mathrm{c}}$ & $112.33 \pm 4.09^{b}$ \\
\hline
\end{tabular}

Each value represents the mean $\pm \mathrm{SE}$.

The mean values with different superscript alphabets indicate significant differences $(\mathrm{P}<0.05)$ using LSD test

Table (8) Effect of prune juice and prune puree on the colon movement in rats (mothers, infant males and infant females)

\begin{tabular}{|c|c|c|c|c|}
\hline \multirow{2}{*}{ Rat group } & \multirow{2}{*}{ Daily intake of mothers group } & \multicolumn{3}{|c|}{ Colon [The length $(\mathrm{cm})$ of barium transfer] } \\
\hline & & Mother's rat & Males & Females \\
\hline G1 & N. Control & $13.5 \pm 0.29^{\mathrm{bc}}$ & $11.17 \pm 0.17^{\mathrm{a}}$ & $13.33 \pm 0.33^{\mathrm{abc}}$ \\
\hline G2 & P. Control 1 (1mg Fe ${ }^{2+} / \mathrm{Kg}$ b.w) & $9.00 \pm 1.15^{\mathrm{d}}$ & $8.00 \pm 0.00^{\mathrm{c}}$ & $11.00 \pm 0.58^{\text {bcd }}$ \\
\hline G3 & $1 \mathrm{mg} \mathrm{Fe}^{2+} / \mathrm{Kg} \mathrm{b.w}+0.5 \mathrm{ml}$ prune juice (twice) & $13.00 \pm 0.00^{\mathrm{c}}$ & $10.00 \pm 0.00^{\mathrm{b}}$ & $12.83 \pm 0.44^{\mathrm{abc}}$ \\
\hline G4 & $1 \mathrm{mg} \mathrm{Fe}^{2+} / \mathrm{Kg} \mathrm{b} . \mathrm{w}+0.5 \mathrm{ml}$ prune puree (twice) & $15.67 \pm 1.33^{\mathrm{abc}}$ & $11.17 \pm 0.17^{\mathrm{a}}$ & $14.07 \pm 0.07^{\mathrm{ab}}$ \\
\hline G5 & P. Control 2 (2.5mg Fe ${ }^{2+} / \mathrm{Kg}$ b.w $)$ & $6.67 \pm 1.20^{\mathrm{d}}$ & $4.50 \pm 0.29^{\mathrm{e}}$ & $9.17 \pm 0.44^{\mathrm{d}}$ \\
\hline G6 & $2.5 \mathrm{mg} \mathrm{Fe}^{2+} / \mathrm{Kg}$ b.w $+0.5 \mathrm{ml}$ prune juice (twice) & $16.67 \pm 1.45^{\mathrm{ab}}$ & $6.50 \pm 0.29^{d}$ & $11.33 \pm 0.33^{\mathrm{bcd}}$ \\
\hline G7 & $2.5 \mathrm{mg} \mathrm{Fe}^{2+} / \mathrm{Kg}$ b.w $+0.5 \mathrm{ml}$ prune puree (twice) & $17.33 \pm 0.67^{\mathrm{a}}$ & $11.33 \pm 0.33^{\mathrm{a}}$ & $15.00 \pm 0.58^{\mathrm{a}}$ \\
\hline
\end{tabular}

Each value represents the mean $\pm \mathrm{SE}$.

The mean values with different superscript alphabets indicate significant differences $(\mathrm{P}<0.05)$ using LSD test

\section{Discussion}

Prune juice is an aqueous extract of dehydrated prunes normalized to $18.5 \%$ solids [30]. The water content and mass of each product change during processing. This must be considered when the phenolic levels of these products are compared because levels are reported on the basis of final mass or volume. During processing, the total amount of soluble solids remains constant because prunes and prune juice had similar levels of phenolic compounds on the basis of total soluble solids; the processing of prune juice from prunes does not appear to significantly degrade phenolic compounds. Phenolic levels in each product were expressed on the basis of mass or volume and total soluble solids content. Data in Table (2) illustrated the phenolic compounds of prune juice and puree. The results show that the main phenolic compounds present in the tested samples were catechin, pyrogallol and chlorogenic acid. The prune juice contains catechin $(41.0 \pm 4.1 \mathrm{mg} / 100 \mathrm{ml})$ and chlorogenic acid $(37.9 \pm 10.2 \mathrm{mg} / 100 \mathrm{ml})$ [31]. Moreover, Donovan et al. [30]showed that phenolic composition of prune juice which contained chlorogenic acid, caffeic acid and coumaric acid were $19.3,0.3$ and $0.4 \mathrm{mg} / 100 \mathrm{ml}$ ), respectively. They illustrated the processing of prune juice from prunes did not appear to significantly degrade phenolic compounds. Halvorsen et al. [32] cited that there weren't enough studies about phenolic compounds of prunes. 
Data in Table (3) illustrate the content of vitamin C in prune juice and puree with the same range in the previously studies by Carlsen et al. [33]. They found that prune juice content of vitamin C was $6.0(\mathrm{mg} / 100 \mathrm{ml})$. Moreover, Franke et al. [34] showed that the vitamin $\mathrm{C}$ content of dried prune was $4.1(\mathrm{mg} / 100 \mathrm{~g})$.

Sugar alcohols (also known as polyols) such as sorbitol and xylitol have been reported to cause laxative action, [35] On the other hand, Stacewicz-Sapuntzakis et al. [14] cited that Prunes and plums are a source of the sugar alcohols xylitol and sorbitol. Data in Table (3) show that the prune juice and puree content of sorbitol and xylitol. It could be noticed that the content of sorbitol and xyitol in prune puree higher than prune juice. These results were agreement with previously studied by Dikeman et al. [36] and Carlsen et al. [33].

After the newborn period and until about 2 years of age, the most common problems with constipation will most likely be "functional" [4]. There is often an association with women who iron intake during the third trimester of pregnancy with constipation [3]. What can we do if the women should be take iron supplements during pregnancy although, these women and their babies suffer from constipation due to that? According to Jaber et al. [1] \& Banhidy et al. [2] who mentioned that the Iron supplementation during pregnancy causes constipation in pregnant women and their newborn babies.

Presented results clearly demonstrate that the prune juice or prune puree have a laxative effects and enhance physical bowel movement. Specifically, classical biomarkers, fecal pellet number, weight and moisture (\%) were increased in prune juice or puree - treated rats compared non-treated rats. Gastrointestinal or colon movement was also increased in prune juice or puree in treated rats. Additionally, reduced fecal excretion in $\mathrm{Fe} 2+$ administered rats compared to normal rats (N. control) confirmed that $\mathrm{Fe} 2+$ induced constipation.

The results showed that fecal output, as measured by fecal number; weight and moisture were significantly elevated in a dose-dependent manner by the administration of prune juice or puree Fig. (1-6) \& Table (4-6). These results indicated that prune juice or puree decreased constipation in the $\mathrm{Fe}^{2+}$ treated rats. In this study, we were unable to clarify the specific mechanisms of the effects of prunes against constipation. However, we suggest that Prunes is a source of the sugar alcohols xylitol and sorbitol. Prunes also contain phenolic compounds, mainly in the form of neochlorogenic and chlorogenic acids, which may assist in the laxative action [14].

These previous studies provide that sorbitol has a laxative effect and brings about changes in intestinal microbiota [17]. Moreover, xylitol increases gastric emptying and decreases intestinal transit time [15], and transforms the intestinal microbiota into more acidproducing ones [16]. Moreover, it could be noticed that the effect of iron intake which due to constipation on female letter than on male. It was may be related to absorption of iron in general is dependent on the physiological status [37].

We also observed increased intestinal transit length [The length $(\mathrm{cm})$ of barium transfer] and decreased numbers of fecal pellets in the distal colon in prune juice or puree administered rats (Table $7 \& 8$ ).

The positive effects of prune juice on gastrointestinal function were seen only after 2 weeks of its regular consumption.

The mild laxative effect appeared to continue even into the follow-up week after the rats administered prune juice and prune puree. In previous studies, a similar mild positive effect on gastrointestinal function and a relieving effect on constipation have been reported [12].

Presented data confirmed that prune puree has a more positive effective than prune juice on fecal moisture and gastrointestinal movement in rats administrated with 1 or $2.5 \mathrm{mg} \mathrm{Fe} 2+/ \mathrm{Kg}$ bw, due to the chlorogenic acid, xyitol and sorbitol of prune juice was less than of prune puree; the other reason; to discuss this result the prune puree contain fiber more than prune juice [10].These results agreement with Bosaeus [38] who stated that some studies on bowel function and intestinal disease have used high-fiber diets. Increased fiber intake will generally increase stool weight. The magnitude of the increase varies with the fiber source. The contributions of this increase from an elevated bacterial mass, feces water and undigested fiber also vary markedly with the type of fiber.

Sorbitol and xylitol have been reported to cause laxative action [35]. Like the indigestible fiber found in prunes, nondigested sorbitol and xylitol may pass into the colon and be fermented there [17]. This increases bacterial mass and may in turn increase fecal bulk and soften stools.

On the other hand, nondigested sorbitol can soften stools because of its ability to hold moisture, the so-called humectant effect, well known and used by the cosmetics and food industries [14].

Piirainen, et al. [18] found that regularly ingested prune juice had a mild laxative effect adult with certain gastrointestinal symptoms. However, consumption of prune juice also increased flatulence. Because the taste of the product was well accepted, it may offer a user-friendly alternative to laxatives, at least in cases of mild constipation.

In conclusion, the results suggested that prune juice or puree can regulation intestinal movement, subsequently decreased constipation via normalizing the bowel movement resulting from the $\mathrm{Fe}^{2+}$ administrated in pregnant rats and their puppies (newborns and infants rats).

\section{Acknowledgment}

The authors would like to thanks Dr. Redaa Ahmed Raàft Elmalla, Veterinarian director in charge of Animal House, in the Ophthalmology Research Institute, Giza, Egypt, for his guidance and help us during experiment. 


\section{References}

[1] Jaber, L.; S. Rigier; A. Taya; F. Tebi; M. Baloum; I. Yaniv; M. Hai Yehia, and H. Tamary (2010) Iron polymaltose versus ferrous gluconate in the prevention of iron deficiency anemia of infancy. J Pediatr Hematol Oncol 32(8):585- 588.

[2] Banhidy, F; N. Acs; E.H. Puho, and A.E. Czeizel (2011). Iron deficiency anemia: Pregnancy outcomes with or without iron supplementation. Nutrition 27(1):65- 72

[3] Penn, Z. (2005) Gastrointestinal problems pregnancy. Other problems in pregnancy, Women Health Medicine 2:2, The Medicine Publishing Company Ltd. 38-39.

[4] Nicolett, L. (2011) constipation Mattei (ed.), Fundamentals of Pediatric Surgery chapter 58

[5] Ward, R.J.; S. Wilmet; R. Legssyer, and R. R. Crichton (2003) Iron supplementation during pregnancy-A necessary or toxic Supplement? Bioinorganic Chemistry and Applications; 1 (2): 169-176

[6] Lachili, B.; I. Hininger; H. Faure; J. Arnaud; M.J. Richard; A. Favier, and A.M. Roussel (2001) Increased lipid peroxidation in pregnant women after iron and vitamin $\mathrm{C}$ supplementation. Biol. Trace Elem. Res. 83 (2): 103 -110.

[7] Schill T.O. and T. Reilly (2000) Anemia, iron and pregnancy outcome. J. Nutr. 130: 443.

[8] Haram K., S.T. Nilsen, and R.J. Ulvik (2001) Iron supplementation in pregnancy - evidence and controversies. Acta. Obstet. Gynecol. Scand. 80 (8): 683 - 688

[9] Cabré, E. (2011) Clinical Nutrition University: Nutrition in the prevention and management of irritable bowel syndrome, constipation and diverticulosis. The European J. of Clinical Nutr. and Metabolism 6: e85-e95.

[10] Ferrer F.P. and L.J.Boyd (1955) Effect of yogurt with prune whip on constipation. Am J Dig Dis; 9: 272-273.

[11] Muller-Lissner S.A.; V. Kaatz; W. Brandt; J. Keller, and P. Layer (2005) The perceived effect of various foods and beverages on stool consistency. Eur. J. Gastroenterol Hepatol; 17: 109-112.

[12] Tinker L.F.; B.O. Schneeman; P.A. Davis; D.D. Gallaher, and C.R. Waggoner (1991) Consumption of prunes as a source of dietary fiber in men with mild hypercholesterolemia. Am J Clin Nutr; 53: 1259-1265.

[13] Souci, S.W.; W. Fachmann, and H. Kraut (2000) Food composition and nutrition tables. 6th ed. Stuttgart: Medpharm Scientific Publishers, p.900- 903.

[14] Stacewicz-Sapuntzakis, M.; P.E. Bowen; E.A. Hussain; B.I. Damayanti- Wood and N.R. Farnsworth (2001) Chemical composition and potential health effects of prunes: a functional food? Crit Rev Food Sci Nutr; 41:251-286.

[15] Salminen, E.K.; S.J. Salminen; L. Porkka; P. Kwasowski; V. Marks, and P.E. Koivistoinen (1989) Xylitol vs glucose: effect on the rate of gastricemptying and motilin, insulin, and gastric inhibitory polypeptiderelease. Am J Clin Nutr; 49:1228-32.

[16] Salminen, S.; E. Salminen; P. Koivistoinen; J. Bridges, and V. Marks (1985) Gut microflora interactions with xylitol in the mouse, rat and man. Food Chem Toxicol;23: 985-990.

[17] Islam, M.S.; E. Sakaguchi; N. Kashima; and S. Hoshi (2004) Effect of sugar alcohols on gut function and body composition in normal and cecectomized rats. Exp Anim; $53: 361-371$.

[18] Piirainen, L.; K. Peuhkurib; K. Backstromb; R. Korpelab, and S. Salminene (2007) Prune juice has a mild laxative effect in adults with certain gastrointestinal symptoms. Nutr. Res. 27: 511-513.

[19] Reeves, P.G., H. F. Nieilsen, and G.C. Fahey (1993) AIN-93 purified diets for laboratory rodents: final report of the American Instutiute of Nutrition Ad Hoc writing committee on the reformulation of the AIN-76A rodent diet Committee Report American Institute of Nutrition, 53: 1939-1950.

[20] Olienyk, P.; A.R. Gonzalez; A. Mauromoustakos; W.K. Patterson; C.R. Rom, and J. Clark (1997) Nitrogen fertilization affects quality of peach puree. Hort. Sci. 32 (2): $284-287$

[21] Danny, K. A.; Y. J., Hong; D.M. Barrett and A.E. Metchell (2003) Comparison of total phenolic and ascorbic acid content of freeze dried and air dried marinoberry, strawberry and corn grown using conventional, organic and sustainable agricultural practices. $J$. of Food and Agricultural Chemistry. 51, 1237-1241

[22] Romeu-Nadal, M.; S. Morera-Pons; A.I. Castellote, and M.C. Lopez-Sabater (2006) Rapid high-performance liquid chromatographic method for Vitamin $\mathrm{C}$ determination in human milk versus an enzymatic method. $J$. of Chromatography B, 830 (1): 41-46.

[23] Ma, M.; A. DiLollo; R. Mercuri; T. Lee; M. Bundang, and E. Kwong (2002) HPLC and LC-MS Studies of the transesterification reaction of methylparaben with twelve 3to 6-carbon sugar alcohols and propylene glycol and the isomerization of the reaction products by acyl migration. $\mathrm{J}$. of Chromatographic Sci. 40 (3): 170 - 177.

[24] Papea, S.; D. Jeek, and D. Kujundi (2001) Determination of sorbitol concentration in diet chocolate by HighPerformance Liquid Chromatography. Food Technol. Biotechnol. 39 (2): 129-133.

[25] Gambling, L; H.S. Anderson; A. Czopek; R. Wojciak; Z. Krejpcio, and H.J. McArdle (2004) Effect of timing of iron supplementation on maternal and neonatal growth and iron status of iron-deficient pregnant rats. J Physiol 561(1): 195203.

[26] Erichsen, K.; A.M. Milde; G. Arslam; L.Helgeland; O.A. Gudbrandsen; R.K. Berge; T. Hausken, and A. Berstand (2005) Low dose oral ferrous fumarate aggravated intestinal inflammation in rats with DSS-induced colitis. Inflamm Bowel Dis. 11(8): 744- 748.

[27] A.O.A.C. (2000) Official Methods of Analysis. Association of Official of Agricultural Chemists. 17 th ed., Washington D.C.

[28] Kim, J. H.; S. C. Park; J. Y. Kim, and Y. K. Park (2009) The Effect of Probiotic on Constipation in Rats. J. of Med. 26 (2): 102-107.

[29] Herranz, N. and J. Ruiz-Castillo (2012) Sub-field normalization in the multiplicative case: Average-based citation indicators. J. of Informetrics 6(4): $543-556$. 
[30] Donovan, J.L.; A.S. Meyer, and A.L. Waterhouse (1998) Phenolic composition and antioxidant activity of prunes and prune juice (Prunus domestica). J. Agric. Food Chem. 46, $1247-1252$

[31] Gorsel, H.V.; C. Li; E.L. Kerbe1; M. Smits, and A. Kader (1992) Compositional Characterization of Prune Juice. $J$. Agric. Food chem. 40: 784-789.

[32] Halvorsen, B.L.; M.H. Carlsen; K. M. Phillips; S.K. Bohn; K. Holte; D.R. Jacobs, and R. Blomhoff (2006) Content of redox-active compounds (ie, antioxidants) in foods consumed in the United States. Am. J. Clin. Nutr. 84:95-315.

[33] Carlsen, M.H.; B.L. Halvorsen; K. Holte; S.K. Bohn; S. Dragland; L. Sampson; C. Willey; H. Senoo; Y. Umezono; C. Sanada; I. Barikmo; N. Berhe; W.C. Willett; K.M. Phillips; D.R. Jacobs, and R. Blomhoff (2010) The total antioxidant content of more than 3100 foods, beverages, spices, herbs and supplements used worldwide. J. Nutr. 9:3-13.

[34] Franke, A.A.; L. J. Custer; C. Arakaki, and S.P. Murphy,
(2004) Vitamin C and flavonoid levels of fruits and vegetables consumed in Hawaii. J. of Food Composition and Analysis 17: 1-35.

[35] Lebenthal-Bendor, Y.; R.C. Theuer; A. Lebenthal; I. Tabi, and E. Lebenthal (2001) Malabsorption of modified food starch (acetylated distarch phosphate) in normal infants and in 8-24-month-old toddlers with non-specific diarrhea, as influenced by sorbitol and fructose. Acta Paediatr ;90: $1368-1372$

[36] Dikeman, C.L.; L.L. Bauer, and G.C. Fahey (2004) Carbohydrate composition of selected plum/prune preparations. J. Agric. Food Chem. 52 (4): 853-859.

[37] Nair, K.M. and V. Iyengar (2009) Iron content, bioavailability \& factors affecting iron status of Indians. Indian J. Med Res. 130 (11):634-645.

[38] Bosaeus I (2004) Fiber effects on intestinal functions (diarrhea, constipation and irritable bowel syndrome). linical Nutrition Supplements 1, 33-38. 